\title{
Impact of Social Media Marketing on Consumer's Purchase Intentions: The Mediating role of Customer Trust
}

\author{
Umair Manzoor ${ }^{* 1}$, Sajjad Ahmad Baig ${ }^{2}$, Muhammad Hashim ${ }^{3}$, Abdul Sami $^{4}$ \\ ${ }^{1.2 .3}$ Department of Management Sciences, National Textile University, Faisalabad \\ ${ }^{4}$ Department of Management Sciences, University of Jhang
}

* Corresponding author: umairmanzoor50@gmail.com

Submission: 31 May $2020 \quad$ Revised: 12 June $2020 \quad$ Published: 21 July 2020

\begin{abstract}
Successful marketing and promotion strategies achieve customer development, profitability, and long-term company success. Present markets become more competitive through changing markets, globalization, and innovative technology, which have rapidly changed the business world. Platforms like Facebook, Twitter, and YouTube are pushing marketing companies toward a new direction using social media marketing. Social media has penetrated so deeply into millions of people's lives worldwide that it has also attracted marketers' attention. This study will help determine how it influences Pakistani consumers' purchase intentions. This research used a quantitative method based on primary data. The data was collected from Faisalabad, and the sample size was 250 participants. Among the 250 questionnaires, 190 are useable. The results show that trust and social media influence significantly affect consumers' purchase intentions. Data analysis reveals that social media marketing has a greater influence than trust in purchase intentions through social networking sites. Therefore, improving websites' quality enhances customers' trust. Hence, trust plays an important role in e-commerce by directly influencing the purchasing intentions of customers.
\end{abstract}

Keywords: Social Media Marketing, Purchase Intention, Trust, Online Advertisement

\section{INTRODUCTION}

In this modern era, technology plays a great role in our daily lives (De Mooij, 2019). The technology has brought significant changes and it has influence every aspect of individuals lives (Sami \& Irfan, 2018). The internet is one of the essential parts of technology. The internet is responsible for giving a place where people, companies and other individuals can communicate, and different companies can advertise their products or services to increase their market share (Chaffey \& Ellis-Chadwick, 2019). The internet gives various features that can help to gather large numbers of loyal and potential customers. Consumers use it for multiple reasons, such as collecting information related to online purchasing. Purchasing through the internet is said to be safer and quicker. People spend a short time buying things on the internet. However, analysts predict that it will increase tremendously, because people now feel safe and secure buying online, and they also think that their time savings will also change the way people communicate (Gilchrist, 2016).

The development of social media provides opportunities for firms as an impressive marketing tool. Social media marketing is defined as marketing that uses social networking websites as a marketing channel (Kujur \& Singh, 2017). Social media is an essential tool for economic growth as its tools include two-way communication and low-cost marketing to obtain information, connect and establish a relationship with its clients (Irfan et al., 2019). Social media marketing aims to help the companies to increase their market share and purchase inte ntions of their customers. In the last 40 years, we have seen that the way people interact has changed. The emergence of the social media network has had a tremendous impact on business strategies and brings a drastic change in marketing strategies (Irfan et al., 2017). The use of social media technologies is growing, and, in the future, we should expect it to have the same effect on businesses. With new technologies available, companies that learn to use them gain considerable advantages. Among the top examples are technologies like Microsoft, eBay, Amazon and Google. Social media has quickly become one of today's most popular youth outlets. The newest marketing trend is social media marketing, and business owners want to learn how it can create interest in their business. In the decision-making cycle of consumers, social media plays a very important role. Platforms like Facebook, LinkedIn, Hi5, YouTube and Twitter have made it easy for consumers to post reviews of products and reach out to other like-minded people in their communities.

Before people make purchases nowadays, they are increasingly reaching out first to their social media communities for opinions (N. Hajli, 2015). Consumers access online groups through social media to understand their views and get a better sense of a product or service (Dedeoğlu et al., 2020). In the fields of marketing, advertisement and communication, social media is much more relevant, with the number of users increasing dramatically every year (Appel et al., 2020). Customers who have a close relationship with a firm share their interactions on social media with other people and suggest the goods or services of the company to their friends through positive word of mouth. The consumers' purchase intentions have always been an important marketing topic extensively studied, debated, and discussed in contemporary textbooks. Social media technology has created radically new ways of connecting retailers and consumers (Iacobucci \& Hoeffler, 2016). Social media has various channels, such as email, internet, and mobile marketing. According to (Appel et al., 2020) Thousands of social networking sites (i.e., 
forums, chat groups, blogs, wikis, podcasts and videos) are unquestionably accessible online. (Zulqurnain et al., 2016) said, social media marketing provides a "connection between brands and consumers while offering a personal channel and currency for user-centered networking and social interaction". (Chaffey \& Ellis-Chadwick, 2019) said that Consumers already demand 24-hour access to information through web apps and several other automated means; they are now requesting 24-hour customer support and self-help services from online outlets. Consumers now want to abandon the conventional information system and use new technologies. The primary and dominant market outlet for goods is now social media (Wang \& Yu, 2017).

\section{Research Gap}

Previous studies have inspected the impact of social media marketing on consumer's purchase intentions. This research will address the gap in how social media marketing influences consumers' purchase intentions in Pakistan. There is some literature on the effects of social media marketing on consumer behavior and perception. Still, there are not enough reviews that provide marketers with information on how social media marketing affects consumers' purchase intentions. The gap that has to be identified is the mediating role of trust between social media marketing and consumer's purchase intentions as well as the direct effects of social media marketing on consumers' purchase intentions.

\section{Research Objectives}

1. To investigate the relationship between social media marketing and customer trust

2. To study the connection between trust and consumer's purchase intention

3. To examine the moderating role of trust between social media marketing and consumer's purchase intention

4. To investigate the overall impact of social media marketing on consumer's purchase intentions

\section{LITERATURE REVIEW}

Social network sites or social network services (SNSs) allow people to establish personal web pages and connect with friends to share information and communicate (Shen et al., 2016). The links built on social networking sites, like most social media websites, are focused primarily on the real life of social networks. Users are allowed to supply real personal data as businesses market shares and products are affected, to a large extent, by the data and user-generated information on the Internet (Kapferer \& Bastien, 2012). Social media analytics offers businesses competitive advantages by providing information on their competitors' strategies, suppliers' performance, consumers' trust, and consumers' purchase intentions (Fan \& Gordon, 2014). Social media is an instrument used to raise awareness about goods and services through organizations, big or small, commercial and non-profit. E-commerce has become more customer-driven by social media (Sin et al., 2012).

Social media proliferation has caused a dramatic shift in interactions. In their integrated marketing strategy, Smart companies implemented social media platforms to extend their current client base and draw new customers for accelerated growth and increased market shares (Tiago \& Veríssimo, 2014).

\section{Social Media}

To make online marketing successful, social networking sites play an important role (Irfan et al., 2018). Social media offer different values to organizations by enhancing brand popularity (Al-Sheikh \& Hasanat, 2020), facilitating word-of-mouth communication (Li \& Wu, 2018), growing sales (Coursaris et al., 2016), Sharing data in a company sense (Wright, 2019), and build customer social support (Naeem, 2019). Instead, networking Social media shows that values which have a positive impact on consumer trust (M. N. Hajli, 2014). With expanding social media and networking services, studying consumer trust and purchase intentions on these platforms is a research agenda (Javornik, 2016). Social media may create strategies for marketing in companies through confidence-building mechanisms, which influence consumer intentions to buy products online (Usman \& Okafor, 2019).

A new field of content creation has grown with the growth of social networks, where anyone can quickly exchange knowledge and experience with other people (Chen et al., 2011). Online communities provide an incentive and forum for a stronger customer service management framework for both businesses and organizations (Ang, 2011), Bringing in a new era where businesses can boost efficiency. In addition, members can get connected on sites that provide a possible source of trust and social experiences. (Y. Lu et al., 2010). Social media offers businesses new ways to become more universally attractive (Aksoy et al., 2013). This can significantly influence consumer purchase intentions (Prendergast et al., 2010). Social networking, such as online forums, groups, ratings, feedback and recommendations, which create social support online, enabled such social interactions. This could increase the trust of e-commerce dealers and buyers. Moreover, studies on social media allow us to see how people shape their online social interactions (Kuss \& Griffiths, 2011).

\section{Customer's Trust}

Trust in the e-seller is important in a business-to - consumer partnership when evaluating risk in all transactions (Harris \& Goode, 2004). In e-commerce, trust is an essential (Kwortnik Jr \& Han, 2011). Trust is represented differently, but all are based on different dimensions of honesty, capacity, competence and recognition (Pirson et al., 2017). Even then, the risk and ambiguity in the online world are both concepts and dimensions. The two key dimensions of trust that this work draws on are compassion and integrity (Ceglarz et al., 2017). Trust based on credibility relies on reputation and refers to the assumption that the other party in a transaction is trustworthy, whereas benevolence relates to consistent relationships between seller and buyer (Joshi \& Sharma, 2019). In this study, trust is perceived across online communities in the sense of transactions over the internet.

Trust in peers on social networking services will also be considered. When it comes to online communities, trust can help in the interactions of individuals and encourage them to attach others to their current network. Moreover, trust plays a significant part in defining both a consumer's purchase intention and actual behavior (Chiu et al., 2012; Keh \& Xie, 2009).

\section{Consumers Purchase Intentions}

The company dictionary's basic meaning of purchasing intentions is a decision to buy a specific product or service. Nevertheless, purchase intentions come from behavioral science and change from the term intention (Oosthuizen et al., 2015). Consumer's purchase intentions are 
defined as a combination of their interest and the possibility of buying a product. Consumers' purchase intentions are an attitudinal variable for measuring their future contributions to buying products. Since forecasting consumers' future behavior is a critical issue for organizations; hence, it should be estimated more clearly (Baabdullah et al., 2019). The formation of consumer's purchase intentions depends on their general attitudes towards a particular product (Cheruiyot \& Maru, 2013). The better these attitudes are, the better the purchasing intentions (Gremler et al., 2001). A similar definition was also proposed (Beneke et al., 2013; Faryabi et al., 2015; Wu, 2015) all of whom focused on the consumers' willingness to buy a specific product. Instead of suggesting a high risk of actually making a purchase, positive purchasing intentions often reflect the positive engagement or loyalty of the customer toward products (Hong \& Cho, 2011). According to (Farah, 2017), Intention indicates the subjective likelihood that a specific action will be performed. The idea has been stretched to consumers' purchase intentions, which describes the probability that consumers will execute the buying action (Kahraman \& Kazançoğlu, 2019). (N. Hajli et al., 2017) stated that consumers' purchase intentions indicate predictable behavior, which means that purchase intentions can be used to forecast what items customers should buy when they go shopping next time.

\section{Model Development and Hypothesis}

The research model proposes to examine the relationships between the constructs of social media, customer trust, and consumer purchase intentions.

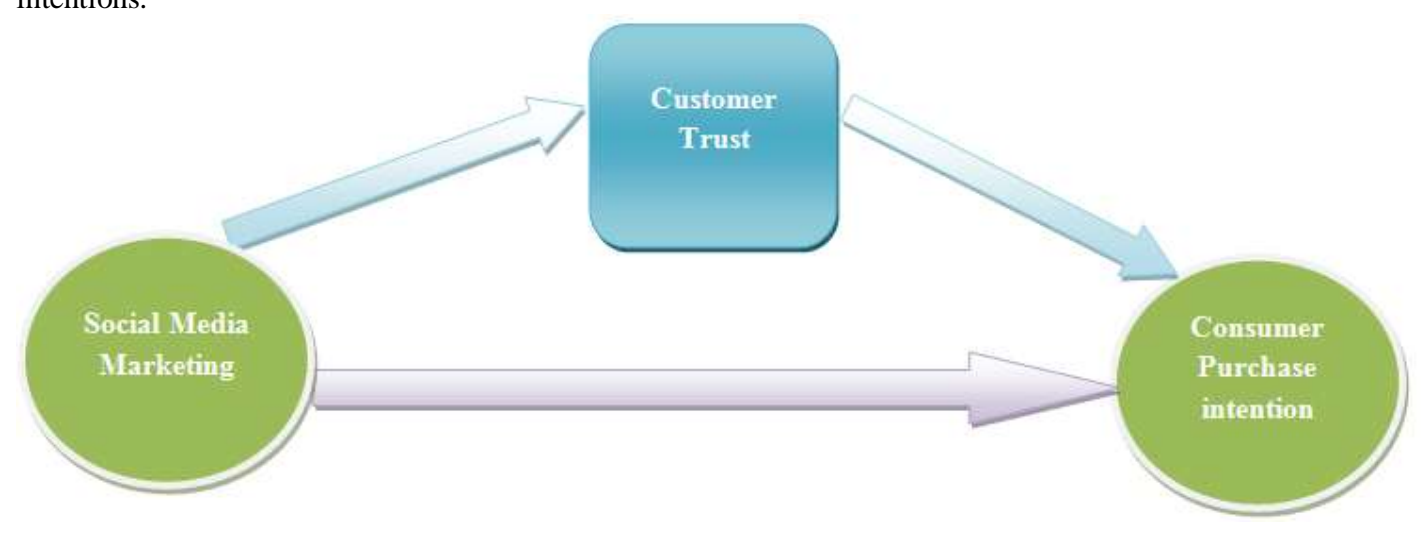

Fig 1. Research Model of the Impact of Social Media on Consumer Purchase Intentions

\section{EFFECT OF SOCIAL MEDIA MARKETING}

Social media marketing is a modern marketing technique that is practiced by almost every company in virtual networks to reach out to customers. When you have an idea and want millions to be reached quickly with minimal costs, the best option is social media. The first businesses to use social media as a promotional platform were entertainment companies. (Karimi \& Naghibi, 2015) defined social media marketing as a mechanism that allows anyone to advertise their blogs, goods or services online to reach a wider audience that is not accessible via traditional channels. Therefore, if we keep it clear, social media marketing is the mechanism by which businesses use social media platforms to concentrate on their official websites. It does not end there, as it is possible for organizations, by social media use, to remind potential clients of activities in the company, to introduce a new concept or product, and to relate news about the company. (Kyriakopoulou \& Kitsios, 2017) have linked social media marketing to marketing relationships, suggesting that companies will switch from the 'seek to sell' model to the 'make ties' with customers model. The social media marketing theory brings us to the other side of the marketing field, where relationship building with potential customers is the secret to repeated transactions and increased brand loyalty. Social networking is a new method that companies use to create good public relations with consumers on wireless servers (He et al., 2017). Public relations via social media have become easier to manage since a vast number of potential customers are on virtual networks, and social networking is just a few steps away. Customers today are more powerful than ever, as customers have been named king; businesses should be available and open on every social media platform, including Facebook, Twitter, blogs, and internet forums (Wigmo \& Wikström, 2010). Social media communication channels provide essential opportunities for every organization. Social support develops through social media interactions; therefore, it affects trust (N. Hajli, 2015). More positive reviews, feedback and ratings also contribute to greater trust (Utz et al., 2009). The social relationship of consumers developed through social media significantly affects the consumer's trust (Chahal \& Rani, 2017). Previous studies found that customer reviews' consistency and quantity of information affect consumer purchasing decisions by increasing consumer trust (Lien et al., 2015).

- H1: Social media marketing positively affects consumer purchase intentions.

- H2: Social media marketing positively affects customer trust.

\section{EFFECT OF CUSTOMER'S TRUST}

One of the major requirements for strong customer purchase intention in an online environment and social media is customer trust (B. Lu et al., 2016). In marketing, the customer's trust is generally defined as the willingness of a customer to revisit a brand (Ramanathan et al., 2017). Trust is two-directional; one direction is a belief, and the other is intent (Lim, 2015). Customer trust is a positive expectation and willingness to purchase (Chinomona, 2015). Consumers perceive social media as more trustworthy than the traditional elements of the promotion mix (Schivinski \& Dabrowski, 2016). This may be due to the fact that social media provides direct networking, instant feedback and more real content created by customers. A consumer's trust in the transaction and the network influences the online buyers (Pappas, 2016) and enhances purchase intentions (N. Hajli et al., 2017). Therefore, the customer's trust plays a vital and significant role in the proposed model of this research (Saleem et al., 2017). Trust is an important determinant when considering a consumer's purchase intentions (Basha \& Lal, 2019). More trust by consumers correlates with an increased intention to purchase (Hasbullah et al., 2016). Therefore, the customer's trust is likely to affect intentions to transact (Ofori et al., 2017).

- H3: Customer's trust has a positive effect on consumer's purchase intentions.

- H4: Customer's Trust mediates the relationship between social media marketing and consumer's purchase Intentions. 


\section{RESEARCH METHODOLOGY}

This research surveyed people to test the proposed model. This research was conducted through paper questionnaires. The participants were mostly residents of Faisalabad, Pakistan, and this study focuses on users of social media websites who have some information about social media marketing on those websites.

\section{Research Design}

This research used a quantitative method that was based on primary data. According to the rese arch requirements, this study needed data to analyze the behavior of Pakistani consumers. For this purpose of the study, we used social media users.

\section{Research Population}

Data was collected from Faisalabad, which is a major city in Pakistan. The consumers in Faisalabad are an urban population, are very aware of social media websites, and are relevant to this research. The target audience was social media users. The questionnaire was distributed in Faisalabad, Pakistan. The target individuals were members of social networking sites such as Facebook, Twitter, hi5, LinkedIn, etc.

\section{Sample Size}

The sample size for this study was 250. A total of 250 questionnaires were offered in Faisalabad; 210 questionnaires were received, but 20 out of 210 were rejected, so only 190 questionnaires were usable.

\section{Statistical tool/ Analysis}

SPSS software is used in this study to analyze the results.

\section{Data collection method}

\section{Primary Data \& MEASURING INSTRUMENTS}

This study used the " 5 -Point Likert scale, ranging from $1=$ strongly disagree to $5=$ strongly agree". To increase the validity of the study, the measures in the questionnaire were adapted from previous research of (M. N. Hajli, 2014). Trust, one of the essential variables included in the model, was investigated in a number of previous research studies. The dependent variable of this study is the purchase intention. This construct measures the user's willingness and intention to purchase on social network services. Survey questionnaires were distributed among users of social media sites.

Social Media Marketing measures: (Smith, 2014)

1. "Do you think that social media makes your life easier?"

2. "I am very enthusiastic to find the description of products on electronics platform like internet, email or web."

3. "Do you think social media provide accurate and proper knowledge of products and services?"

4. "Social Media innovates the ways of advertising products or services in an efficient manner."

5. "Do you like to adopt the way of buying and selling of products or services using social media?"

6. "Do you think social media marketing inspire you to make a buying decision?"

7. "I like to spend more time on social media because I like to see what the latest fashion is?"

8. "By using advertising messages via the mobile phone I can demonstrate my innovativeness to my friends."

Measures for Customer's trust: (Naylor et al., 2012)

1. "I will probably buy a product on the internet (Soon)."

2. "I feel capable of finding shopping verity and information on the social media websites."

3. "Social Media marketing keeps me up to date about new products and Services."

4. "In general, I am satisfied with the service provided by the internet"

5. "I am satisfied on social media services about marketing."

Measures for Consumer "purchase Intentions: (McKnight et al., 2002)

1. "I think shopping on the internet saves my time."

2. "It is a great advantage for me to buy product at any time of the day on the internet."

3. "It is more difficult to shop on the internet."

4. "I will prefer online shopping only if online prices are lower than Actual price."

5. "A long time is required for the delivery of products and services on the internet."

6. "Online shopping is as secure as traditional shopping."

7. "The information given about the products and services on the internet is sufficient."

\section{SECONDARY DATA}

This study used different databases such as Science Direct, Webley, Elsevier, Wikipedia, University Library, and other official databases, books, newspapers, and published articles, etc. to encourage and support the study in order to complete this research.

\section{Questionnaire Development}

This study includes eight items of social media marketing, five items of trust, and seven items of consumer's purchase intentions. In the previous study of (M. N. Hajli, 2014), the reliability of eight items of social media marketing was $\alpha=0.8711$, customer's trust was $\alpha=0.8137$, and 
International Journal of Entrepreneurial Research Vol. 3, No. 2 consumer's purchase intentions was $\alpha=0.7593$. All were conducted with a " 5 -point Likert scale ranging from $1=$ strongly disagree to $5=$ strongly agree".

\section{Results and Data Analysis}

The model's reliability and validity have been considered. They are discussed separately in the following sections.

\section{RELIABILITY}

Composite reliability should exceed 0.70 , and it has been applied to test the survey's reliability (Wasko \& Faraj, 2005). The rate is above 0.70 , which indicates "internal consistency". The "internal consistency" is also measured by "Cronbach's alpha" and is above 0.70 . These results confirm the research's reliability (Naylor et al., 2012).

Table 1. Cronbach's Alpha

\begin{tabular}{llll}
\hline & Cronbach's Alpha & No of Items & Adopted from \\
\hline Social Media Marketing & .746 & 8 & (Smith, 2014) \\
Trust & .788 & 5 & (Naylor et al., 2012) \\
Purchase Intention & .764 & 7 & (McKnight et al., 2002) \\
\hline
\end{tabular}

\section{Table 2. Correlation}

\begin{tabular}{|c|c|c|c|c|}
\hline Model Elements & & SM Mean & T mean & PI mean \\
\hline Social Media Marketing & $\begin{array}{l}\text { Pearson Correlation } \\
\text { Siq. (2-tailed) }\end{array}$ & 1 & & \\
\hline Customer's trust & $\begin{array}{l}\mathrm{N} \\
\text { Pearson Correlation } \\
\text { Sig. (2-tailed) }\end{array}$ & $\begin{array}{l}190 \\
.658 * \\
.000\end{array}$ & 1 & \\
\hline $\begin{array}{l}\text { Customer's Purchase } \\
\text { Intentions }\end{array}$ & $\begin{array}{l}\text { Pearson Correlation } \\
\text { Sig. (2-tailed) }\end{array}$ & $\begin{array}{l}.696 " * \\
.000\end{array}$ & $\begin{array}{l}.700^{* *} \\
.000\end{array}$ & 1 \\
\hline
\end{tabular}

**. Correlation is significant at the 0.01 level (2-tailed).

Table 3. Model summary ( $\mathrm{H} 1$ : Social media marketing positively affects consumer purchase intentions)

\begin{tabular}{|c|c|c|c|c|c|c|c|c|c|}
\hline Model & $\mathbf{R}$ & R Square & $\begin{array}{l}\text { Adjusted } \\
\text { Square }\end{array}$ & RBeta Coefficient & $\begin{array}{l}\text { Change S } \\
\text { R } \\
\text { Change }\end{array}$ & $\begin{array}{l}\text { Statistics } \\
\text { SquareF Change }\end{array}$ & df1 & df2 & Sig. F Change \\
\hline 1 & $.696^{\mathrm{a}}$ & .484 & .481 & .696 & .484 & 176.467 & 1 & 188 & .000 \\
\hline
\end{tabular}

Table 3 shows the value of R, R2, and the beta coefficient. R2 is .484, which means social media marketing accounts for almost $48 \%$ of the variance in purchase intentions.

Table 4. Model summary (H2: Social media marketing positively affects customer trust)

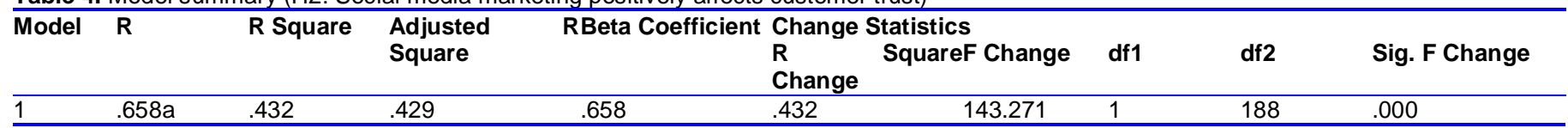

a. Predictors: (Constant), Social Media Marketing mean

In Table 4, R2 is .432, which means social media marketing accounts for almost $43 \%$ of the variance in the trust, whereas $\mathrm{R} 2$ in the effect of social media marketing on consumer's purchase intentions is more than the R2 in the effect of social media marketing on customer trust.

Table 5. Model Summary (Customer's trust has a positive effect on consumer's purchase intentions)

\begin{tabular}{|c|c|c|c|c|c|c|c|c|}
\hline Model & $\mathbf{R}$ & R Square & Adjusted R & Beta Coefficient & Change Statistics & & & \\
\hline & & & Square & & $\begin{array}{l}\text { R Square F Change } \\
\text { Change }\end{array}$ & df1 & df2 & Sig. F Change \\
\hline 1 & $.700^{\mathrm{a}}$ & .490 & .487 & .700 & 180.395 & 1 & 188 & .000 \\
\hline
\end{tabular}

Predictors: (Constant), Customer's Trust mean

Table 5 shows that R2 is .49 , which means customer trust accounts for $49 \%$ of the variance in the consumer's purchase intentions. This value of R2 is greater than in Table 3. It shows that customer trust creates more variance in consumer's purchase intentions than social media marketing.

Table 6. Model Summary (H4: Customer's Trust mediates the relationship between social media marketing and consumer's purchase Intentions)

\begin{tabular}{|c|c|c|c|c|c|c|c|c|c|}
\hline Model & $\mathbf{R}$ & R Square & $\begin{array}{l}\text { Adjusted R } \\
\text { Square }\end{array}$ & Beta Coefficient & $\begin{array}{l}\text { Change S } \\
\text { R Square } \\
\text { Change }\end{array}$ & $\begin{array}{l}\text { stics } \\
\text { F Change }\end{array}$ & df1 & df2 & Sig. F Change \\
\hline 1 & $.700^{\mathrm{a}}$ & .490 & .487 & .427 & .490 & 180.395 & 1 & 188 & .000 \\
\hline 2 & $.766^{\mathrm{b}}$ & .588 & .583 & .415 & .098 & 44.354 & 1 & 187 & .000 \\
\hline
\end{tabular}

a. Predictors: (Constant), Customer's Trust mean

b. Predictors: (Constant), Customer's Trust mean, Social Media Marketing mean

In Table 6, the values of R2 are .487 and .583 . This indicates that customer trust accounts for $49 \%$ to $58 \%$ of the variance in the mediating role between social media marketing and consumer's purchase intention. 


\section{Results}

In Table 3, the significance level is 0 and beta is .696, which means that hypothesis number 1 is accepted. Therefore, social media marketing has a significant $69.6 \%$ effect on consumer's purchase intentions. In Table 4 , the significance level is also 0 ; hence, hypothesis number 2 is accepted. The beta of the second hypothesis is .658, so social media marketing affects customer trust by $65.8 \%$. In Table 5 , the significance level is 0 , signifying the acceptability of hypothesis number 3 . The beta of the third hypothesis is .7 , which denotes that customer trust affects consumer's purchase intention by about $70 \%$. Furthermore, it shows that customer trust has a strong mediating role between social media marketing and consumer's purchase intention. Customer trust's effect on consumer's purchase intention is more than social media marketing. In Table 6, the significance level is 0 ; thus, hypothesis number 4 is accepted. This manifests customer trust's significant mediating role between social media marketing and consumer's purchase intentions.

\section{CONCLUSION}

Social media creates innovative change in the lives of individuals; they use social media for various purposes, including communication, ebusiness, buying, and selling. Recent innovations and advancements on the internet and developments in social media have made individuals' lives easier. These developments have introduced a new method of e-commerce. Present research integrates trust and social media concepts and proposes a model to examine the role social media plays in e-business and social adoption.

The results show that trust and social media's influence significantly affect consumers' purchase intentions. This confirms the relevant hypothesis and answers to the research question. Participants are more likely to buy through social networking sites when experiencing highquality systems or information. Review of data reveals social media marketing has more influence than customer trust on their purchase intentions through social networking sites. The enhancement of the website efficiency therefore enhances customer trust. Other analyzed data confirms that customer trust has a positive and significant effect on their purchase intentions. Once participants accepted the trust, they had more than intent to purchase. This underlines the mediating role of trust in social trade adoption. Trust therefore plays a major part in e-commerce through the direct effect of the buying intention of a consumer.

This research contributes by highlighting the role and impact of social media in e-commerce confidence building. The analysis reveals how social media marketing and social media factors influence a customer's trust and purchase intentions through social media sites.

\section{Implications}

A consumer's purchase intentions are the most reliable indicators that establish a connection between the interest of the customer and the purchase itself. This finding highlights and integrates important factors in the context of the social media marketing that influences purchase intention. In Pakistan, more companies are investing in social media marketing to grow their businesses and increase income. The following suggestions based on empirical results are suggested in the hope of providing insights with which companies can become more effective in marketing through social media and gain returns from investment:

- Companies should choose social media platforms with high sociability and create groups themselves.

- Choose social media platforms on which people rely and spend more time.

The analytical results indicate that the sociability of social media has a positive impact on the trust of the consumer, which then affects buying intentions positively. Empirical results of this research indicate that reliance on social media has a positive effect on customer trust and on the purchasing intentions of both consumers. The theory of media dependence explains that the more people rely on the media to meet their needs, the more important it will be for media to be in the life of a person and have more impact on them. In short, two steps in the marketing of social media advise an organization to establish long-term relationships with consumers and instructing a company to create dependency among consumers. The likelihood of purchasing from that company is high when consumers have needs and trust the company.

\section{Future Research}

By considering the results of the empirical analysis, some suggestions for future research are described as follows. The study of social media marketing is influenced to some extent by referencing theories and empirical results from other fields. In future research, it would be more reasonable to develop alternative models and strategies to see which model demonstrates the best fit. Finally, since this study focuses on the factors influencing the general buying preferences of consumers in the social media marketing sense, future research should investigate the discrepancies in population samples. Examples of this could be the effects of gender or age differences on the influence social media has on consumers' purchase intentions. The use of different social media platforms could be another influence on consumers' purchase intentions. This study ignored external variables such as product-related factors. Future research could include these factors with the influence of social media marketing on consumer's purchase intentions.

\section{References:}

Aksoy, L., Van Riel, A., Kandampully, J., Bolton, R. N., Parasuraman, A., Hoefnagels, A., Migchels, N., Kabadayi, S., Gruber, T., \& Loureiro, Y. K. (2013). Understanding Generation $Y$ and their use of social media: a review and research agenda. Journal of Service Management.

Al-Sheikh, E. S., \& Hasanat, M. H. A. (2020). Social media mining for assessing brand popularity. In Global Branding: Breakthroughs in Research and Practice (pp. 803-824). IGI Global.

Ang, L. (2011). Community relationship management and social media. Journal of Database Marketing \& Customer Strategy Management, 18(1), 31-38.

Appel, G., Grewal, L., Hadi, R., \& Stephen, A. T. (2020). The future of social media in marketing. Journal of the Academy of Marketing Science, 48(1), 79-95.

Baabdullah, A. M., Alalwan, A. A., Rana, N. P., Kizgin, H., \& Patil, P. (2019). Consumer use of mobile banking (M-Banking) in Saudi Arabia: Towards an integrated model. International Journal of Information Management, 44, 38-52.

Basha, M. B., \& Lal, D. (2019). Indian consumers' attitudes towards purchasing organically produced foods: An empirical study. Journal of Cleaner Production, $215,99-111$.

Beneke, J., Flynn, R., Greig, T., \& Mukaiwa, M. (2013). The influence of perceived product quality, relative price and risk on customer value and willingness to buy: a study of private label merchandise. Journal of Product \& Brand Management.

Ceglarz, A., Beneking, A., Ellenbeck, S., \& Battaglini, A. (2017). Understanding the role of trust in power line development projects: Evidence from two case studies in Norway. Energy Policy, 110, 570-580.

Chaffey, D., \& Ellis-Chadwick, F. (2019). Digital marketing. Pearson UK.

Chahal, H., \& Rani, A. (2017). How trust moderates social media engagement and brand equity. Journal of Research in Interactive Marketing. 
Chen, C. W., Chen, T. H., \& Lin, Y. F. (2011). Statistical analysis for consumers' intentions of purchasing cosmetics. African Journal of Business Management, $5(29), 11630$.

Cheruiyot, T. K., \& Maru, L. C. (2013). Service quality and relative performance of public universities in East Africa. TQM Journal, 25(5), 533-546. https://doi.org/10.1108/TQM-11-2012-0103

Chinomona, R. (2015). The influence of perceived hypermarket size on perceived hypermarket reputation, trust and customer willingness to purchase in South Africa. Journal of Economics and Behavioral Studies, 7(4), 60-70.

Chiu, C.-M., Hsu, M.-H., Lai, H., \& Chang, C.-M. (2012). Re-examining the influence of trust on online repeat purchase intention: The moderating role of habit and its antecedents. Decision Support Systems, 53(4), 835-845.

Coursaris, C. K., van Osch, W., \& Balogh, B. A. (2016). Do Facebook likes lead to shares or sales? Exploring the empirical links between social media content, brand equity, purchase intention, and engagement. 2016 49th Hawaii International Conference on System Sciences (HICSS), $3546-3555$.

De Mooij, M. (2019). Consumer behavior and culture: Consequences for global marketing and advertising. SAGE Publications Limited.

Dedeoğlu, B. B., Taheri, B., Okumus, F., \& Gannon, M. (2020). Understanding the importance that consumers attach to social media sharing (ISMS): Scale development and validation. Tourism Management, 76, 103954.

Fan, W., \& Gordon, M. D. (2014). The power of social media analytics. Communications of the ACM, 57(6), 74-81.

Farah, M. F. (2017). Application of the theory of planned behavior to customer switching intentions in the context of bank consolidations. International Journal of Bank Marketing.

Faryabi, M., Fesaghandis, K. S., \& Saed, M. (2015). Brand Name, Sales Promotion and Consumers' Online Purchase Intention for Cell-phone Brands. International Journal of Marketing Studies, 7(1), 167.

Gilchrist, A. (2016). Industry 4.0: the industrial internet of things. Springer.

Gremler, D. D., Gwinner, K. P., \& Brown, S. W. (2001). Generating positive word-of-mouth communication through customer-employee relationships. International Journal of Service Industry Management, 12(1), 44-59.

Hajli, M. N. (2014). A study of the impact of social media on consumers. International Journal of Market Research, 56(3), 387-404.

Hajli, N. (2015). Social commerce constructs and consumer's intention to buy. International Journal of Information Management, 35(2), 183-191.

Hajli, N., Sims, J., Zadeh, A. H., \& Richard, M.-O. (2017). A social commerce investigation of the role of trust in a social networking site on purchase intentions. Journal of Business Research, 71, 133-141.

Harris, L. C., \& Goode, M. M. H. (2004). The four levels of loyalty and the pivotal role of trust: a study of online service dyna mics. Journal of Retailing, 80(2), $139-158$.

Hasbullah, N. A., Osman, A., Abdullah, S., Salahuddin, S. N., Ramlee, N. F., \& Soha, H. M. (2016). The relationship of attitude, subjective norm and website usability on consumer intention to purchase online: An evidence of Malaysian youth. Procedia Economics and Finance, 35, $493-502$.

He, W., Wang, F.-K., Chen, Y., \& Zha, S. (2017). An exploratory investigation of social media adoption by small businesses. Information Technology and Management, 18(2), 149-160.

Hong, I. B., \& Cho, H. (2011). The impact of consumer trust on attitudinal loyalty and purchase intentions in B2C e-marketplaces: Intermediary trust vs. seller trust. International Journal of Information Management, 31(5), 469-479.

Iacobucci, D., \& Hoeffler, S. (2016). Leveraging social networks to develop radically new products. Journal of Product Innovation Management, 33(2), 217-223.

Irfan, A., Rasli, A., Sami, A., \& Liaquat, H. (2017). Role of social media in promoting education tourism. Advanced Science Letters, 23(9), 8728-8731. https://doi.org/10.1166/asl.2017.9959

Irfan, A., Rasli, A., Sulaiman, Z., Sami, A., \& Qureshi, M. I. (2018). Use of social media sites by Malaysian universities and its impact on university ranking. International Journal of Engineering and Technology(UAE), 7(4.28 Special Issue 28), 67-71.

Irfan, A., Rasli, A., Sulaiman, Z., Sami, A., \& Qureshi, M. I. (2019). The Influence of Social Media on Public Value: A Systematic Review of Past Decade. Journal of Public Value and Administration Insights, 2(1), 1-6. https://doi.org/10.31580/jpvai.v2i1.481

Javornik, A. (2016). Augmented reality: Research agenda for studying the impact of its media characteristics on consumer behaviour. Journal of Retailing and Consumer Services, 30, 252-261.

Joshi, S., \& Sharma, A. (2019). A SURVEY ON: HOW ONLINE RATING IS HELPFUL IN BUILDING CONSUMER TRUST.

Kahraman, A., \& Kazançoğlu, İ. (2019). Understanding consumers' purchase intentions toward natural-claimed products: A qualitative research in personal care products. Business Strategy and the Environment, 28(6), 1218-1233.

Kapferer, J.-N., \& Bastien, V. (2012). The luxury strategy: Break the rules of marketing to build luxury brands. Kogan page publishers.

Karimi, S., \& Naghibi, H. S. (2015). Social media marketing (SMM) strategies for small to medium enterprises (SMEs). International Journal of Information, Business and Management, 7(4), 86.

Keh, H. T., \& Xie, Y. (2009). Corporate reputation and customer behavioral intentions: The roles of trust, identification and commitment. Industrial Marketing Management, 38(7), 732-742.

Kujur, F., \& Singh, S. (2017). Engaging customers through online participation in social networking sites. Asia Pacific Management Review, $22(1)$, 16-24.

Kuss, D. J., \& Griffiths, M. D. (2011). Online social networking and addiction-a review of the psychological literature. International Journal of Environmental Research and Public Health, 8(9), 3528-3552.

Kwortnik Jr, R. J., \& Han, X. (2011). The influence of guest perceptions of service fairness on lodging loyalty in China. Cornell Hospitality Quarterly, 52(3), $321-332$.

Kyriakopoulou, E., \& Kitsios, F. (2017). The influence of social media on consumers' behavior. Proceedings of 6th International Symposium and 28th National Conference on Operational Research, 62-66.

Li, X., \& Wu, L. (2018). Herding and social media word-of-mouth: Evidence from Groupon. Forthcoming at MISQ.

Lien, C.-H., Wen, M.-J., Huang, L.-C., \& Wu, K.-L. (2015). Online hotel booking: The effects of brand image, price, trust and value on purchase intentions. Asia Pacific Management Review, 20(4), 210-218.

Lim, J. (2015). INTENTION AS A TWO-DIRECTIONAL PROCESS.

Lu, B., Fan, W., \& Zhou, M. (2016). Social presence, trust, and social commerce purchase intention: An empirical research. Computers in Human Behavior, 56, $225-237$.

Lu, Y., Zhao, L., \& Wang, B. (2010). From virtual community members to C2C e-commerce buyers: Trust in virtual communities and its effect on consumers' purchase intention. Electronic Commerce Research and Applications, 9(4), 346-360.

McKnight, D. H., Choudhury, V., \& Kacmar, C. (2002). The impact of initial consumer trust on intentions to transact with a web site: a trust building model. The Journal of Strategic Information Systems, 11(3-4), 297-323.

Naeem, M. (2019). Role of social networking platforms as tool for enhancing the service quality and purchase intention of customers in Islamic country. Journal of Islamic Marketing.

Naylor, R. W., Lamberton, C. P., \& West, P. M. (2012). Beyond the "like" button: The impact of mere virtual presence on brand evaluations and purchase intentions in social media settings. Journal of Marketing, 76(6), 105-120.

Ofori, K. S., Boateng, H., Okoe, A. F., \& Gvozdanovic, I. (2017). Examining customers' continuance intentions towards internet banking usage. Marketing Intelligence \& Planning.

Oosthuizen, D., Spowart, J., \& De Meyer-Heydenrych, C. F. (2015). The relationship between perceived price and consumers' purchase intentions of private label wine brands. African Journal of Hospitality, Tourism and Leisure, 4(2), 1-17.

Pappas, N. (2016). Marketing strategies, perceived risks, and consumer trust in online buying behaviour. Journal of Retailing and Consumer Services, $29,92-103$.

Pirson, M., Martin, K., \& Parmar, B. (2017). Formation of stakeholder trust in business and the role of personal values. Journal of Business Ethics, 145(1), 1-20.

Prendergast, G., Ko, D., \& Siu Yin, V. Y. (2010). Online word of mouth and consumer purchase intentions. International Journal of Advertising, 29(5), 687-708.

Ramanathan, U., Subramanian, N., \& Parrott, G. (2017). Role of social media in retail network operations and marketing to enhance customer satisfaction. 
International Journal of Operations \& Production Management.

Saleem, M. A., Zahra, S., \& Yaseen, A. (2017). Impact of service quality and trust on repurchase intentions-the case of Pakistan airline industry. Asia Pacific Journal of Marketing and Logistics.

Sami, A., \& Irfan, A. (2018). Effect of Latest Technology and Social Media on Interpersonal Communication on Youth of Balochistan Effect of Latest Technology and Social Media on Interpersonal Communication on Youth of Balochistan. August.

Schivinski, B., \& Dabrowski, D. (2016). The effect of social media communication on consumer perceptions of brands. Journal of Marketing Communications, 22(2), 189-214.

Shen, G. C.-C., Chiou, J.-S., Hsiao, C.-H., Wang, C.-H., \& Li, H.-N. (2016). Effective marketing communication via social networking site: The moderating role of the social tie. Journal of Business Research, 69(6), 2265-2270.

Sin, S. S., Nor, K. M., \& Al-Agaga, A. M. (2012). Factors Affecting Malaysian young consumers' online purchase intention in social media websites. ProcediaSocial and Behavioral Sciences, 40, 326-333.

Smith, T. M. (2014). Consumer Perceptions of a Brand's Social Media Marketing.

Tiago, M. T. P. M. B., \& Veríssimo, J. M. C. (2014). Digital marketing and social media: Why bother? Business Horizons, 57(6), 703-708.

Usman, A., \& Okafor, S. (2019). Social Media and Purchase Intentions: Strategic Marketing Implications. Harnessing Omni-Channel Marketing Strategies for Fashion and Luxury Brands, 83.

Utz, S., Matzat, U., \& Snijders, C. (2009). On-line reputation systems: The effects of feedback comments and reactions on building and rebuilding trust in on-line auctions. International Journal of Electronic Commerce, 13(3), 95-118.

Wang, Y., \& Yu, C. (2017). Social interaction-based consumer decision-making model in social commerce: The role of word of mouth and observational learning. International Journal of Information Management, 37(3), 179-189.

Wasko, M. M., \& Faraj, S. (2005). Why should I share? Examining social capital and knowledge contribution in electronic networks of practice. MIS Quarterly, $35-57$.

Wigmo, J., \& Wikström, E. (2010). Social Media Marketing: What role can social media play as a marketing tool?

Wright, M. C. (2019). Social Media Data Strategies Bankers Use to Increase Customer Market Share.

Wu, C.-S. (2015). A STUDY ON CONSUMERS'ATTITUDE TOWARDS BRAND IMAGE, ATHLETES'ENDORSEMENT, AND PURCHASE INTENTION. International Journal of Organizational Innovation, 8(2).

Zulqurnain, A. L. I., SHABBIR, M. A., RAUF, M., \& HUSSAIN, A. (2016). To Assess the Impact of Social Media Marketing on Consumer Perception. 